\title{
Declaración de Punta del Este acerca de la resistencia a los antibacterianos en América Latina
}

\author{
Comité de Resistencia a Antibacterianos. Asociación Panamericana de Infectología. \\ Declaration of Punta del Este concerning antimicrobial resistance \\ in Latin America
}

\begin{abstract}
API José María Casellas APUA Aníbal Sosa OPS Pilar Ramón-Pardo Past President API Sergio Cimerman

Agradecemos la colaboración de los revisores de esta declaración, Dres Mirta Quinteros, Gabriel Gutkind, Gabriel Levy Hara, Hélio Vasconcellos Lopes, Juana Ortellado, María Isabel Fernández, Anahí Dreser y Gabriela Tomé Presidente: Eduardo Savio Secretario Científico: Julio Medina

Punta del Este, 7 de Abril de 2011 -Día Mundial de la Salud

Auspiciado por: APUA, OPS y API.

Esta declaración es consiguiente a la Declaración de Guadalajara del $1^{\circ}$ de Mayo de 2001.

L a resistencia bacteriana se ha intensificado en esta última década (2001-2011) dificultando la elección de antibacterianos (comúnmente llamados antibióticos), tanto para el tratamiento de infecciones adquiridas en la comunidad, como para aquellas originadas en el ámbito hospitalario.

En los últimos años se han incrementado las infecciones por bacterias multi-resistentes, también conocidas por la prensa como las “superbacterias”, causantes de una elevada mortalidad.

La resistencia bacteriana representa ya una amenaza para la salud pública de América Latina. Por este motivo, expertos en enfermedades infecciosas de la región hacen un llamado a que gobiernos, industria, profesionales de la salud y la sociedad civil realicen acciones concertadas para contener la resistencia a los antibacterianos y salvaguardar estos importantes medicamentos para las futuras generaciones.
\end{abstract}

\section{Fundamentos}

\section{Infecciones hospitalarias}

En este ámbito, el riesgo de adquirir infecciones producidas por cepas multi-resistentes o extremadamente resistentes se incrementa en función de:

- El indudable desarrollo técnico y científico que ha llevado a mejoras en las posibilidades de vida, especialmente en prematuros, personas de la tercera edad y en pacientes con diferentes compromisos, determinando una población hospitalaria con mayor riesgo de morbilidad y mortalidad.

- El lapso de internación de los pacientes.

- El incremento de maniobras invasoras (Ej.: ventilación mecánica o colocación de catéteres urinarios, intravenosos o intraarteriales) especialmente en las unidades de cuidados intensivos.

- El incremento de la colocación de elementos protésicos (reemplazos óseos, marcapasos, "stents” coronarios, etc.).

- Incremento en medios hospitalarios de bacilos gram- negativos con múltiples mecanismos de resistencia ( $\beta$-lactamasas de espectro extendido, hiperproductores de $\beta$-lactamasas cromosómicas y especialmente nuevas y múltiples carbapenemasas que afectan a uno de los últimos recursos en antibacterianos disponibles: los carbapenemes (ej. imipenem, meropenem...).

- El preocupante incremento de la resistencia a fluoroquinolonas (ej. ciprofloxacina, etc.) en Acinetobacter baumannii-calcoaceticus, Pseudomonas aeruginosa y recientemente en Klebsiella pneumoniae.

- Entre los gram-positivos, el aumento de resistencia a vancomicina y nuevos antibacterianos como linezolid o daptomicina, en Staphylococcus y Enterococcus, principales causantes de infecciones graves de alta morbilidad y mortalidad en el medio hospitalario.

\section{Infecciones en la comunidad}

En los últimos años se han incrementado las infecciones por estas bacterias multi-resistentes en la comunidad en pacientes sin relación con el medio hospitalario. El ejemplo más conspicuo son las cepas de Staphylococcus aureus adquiridas en la comunidad que son genéticamente diferentes de las clásicas productoras de infecciones hospitalarias y pueden causar desde infecciones de piel hasta graves lesiones pulmonares o en otros órganos nobles.

Existen otros ejemplos de microorganismos comunitarios resistentes a los antibacterianos empleados para el tratamiento de las infecciones más frecuentes:

- El incremento en la frecuencia de aislamiento de bacilos gram-negativos resistentes en pacientes comunitarios.

- Preocupa la pérdida de actividad de las fluoroquinolonas para infecciones urinarias y respiratorias.

- Es también preocupante la aparición de infecciones por Clostridium difficile, principal productor de diarreas por uso y/o abuso de antibacterianos.

- El notable incremento de la resistencia a macrólidos y azálidos en Streptococccus pneumoniae (una de las causas más frecuente de infecciones respiratorias) y otros gram-positivos. 


\section{Acciones necesarias hacia un cambio}

Si bien la resistencia a los antibacterianos es una preocupación global, en el contexto de América Latina se suman varios problemas que acentúan su gravedad:

- La permanente escasez en muchos países de recursos provenientes de los presupuestos nacionales para salud, lo que es reflejado por la carencia en número y calidad de recursos estructurales, humanos (médicos, microbiólogos, enfermeros, farmacéuticos, etc.) y de gestión.

- La pobreza que continúa siendo dramática y con ella un problema grave para la transmisión de infecciones, debido principalmente al hacinamiento, que no solamente ocurre en el ámbito domiciliario, sino muchas veces en el propio hospital. Además, la falta de recursos para adquirir los antibacterianos es uno de los factores que se asocia con la interrupción precoz de los tratamientos y la dosificación sub-óptima, ambos asociados con el incremento de la resistencia bacteriana.

- Déficit en la información y formación especializada en enfermedades infecciosas, microbiología y epidemiología. Necesidad de facilitar cursos de formación académica de buenas prácticas clínicas para personal médico, de laboratorio, de enfermería y administrativos.

- Pocos hospitales cuentan con un servicio de epidemiología hospitalaria y personal con la formación adecuada.

- La ausencia, en la mayor parte de nuestros hospitales, de Comités de Control de Infecciones y/o los de Uso Racional de Antimicrobianos, que son indispensables para el uso correcto y racional de antibacterianos en un hospital, siendo imprescindible que funcionen en coordinación en un marco formal y productivo, así como debidamente reconocidos y respaldados por la Autoridad Sanitaria local.

\section{Relación con agropecuaria y veterinaria}

- En los países de América Latina con alto nivel de producción ganadera y de granja no hay vigilancia suficiente sobre el abuso de antibacterianos usados en forma masiva con fines no terapéuticos.

- Las encuestas recientes en América Latina evidencian un aumento en el consumo de antibacterianos dirigidos a mascotas, recetados por veterinarios. El empleo excesivo de algunos antibacterianos como rufloxacina y enrofloxacina dio lugar a Escherichia coli resistentes a todas las fluoroquinolonas. Deberían incrementarse las acciones conjuntas entre el sector agropecuario, médicos veterinarios y los dedicados a medicina humana.
- Es importante establecer criterios sobre el tiempo del tratamiento y las clases de antibacterianos permitidos para uso en animales, de forma que se reduzca la resistencia a antibacterianos de importancia crítica para la medicina humana.

\section{El problema de las migraciones y viajes}

Las corrientes migratorias desde centros rurales de un mismo país o países vecinos hacia grandes centros urbanos producen:

- El traslado de bacterias y otros microorganismos de frecuencia y con resistencia regional a dichos centros.

- La exposición de los migrantes a la adquisición de genes codificados de resistencia que abundan en las grandes ciudades por el uso excesivo de antibacterianos.

La adquisición y portación de viajeros provenientes de distintos países del mismo u otros continentes de bacterias con genes de resistencia que no existían en el país en que reside el viajero, es otra de las causas que incrementan la resistencia a los antibacterianos.

\section{Calidad de laboratorios de microbiología}

Sin perjuicio de las evaluaciones de resistencia realizadas por algunos programas de control de resistencia internacionales, éstas no cubren la mayor parte de los laboratorios de un país y sus resultados pueden no reflejar la realidad local.

Es necesario estimular a las Sociedades de Infectología y Microbiología locales a realizar encuestas y controles de calidad externos a los fines de garantizar la calidad de las pruebas de sensibilidad a los antibacterianos. Sería conveniente que los Ministerios de Salud respaldaran estas medidas creando mecanismos eficientes para difundir la información obtenida sobre la resistencia, con el fin de mejorar la prescripción médica y la gestión en servicios de salud, incluyendo educación médica, guías de tratamiento, formularios hospitalarios y listados nacionales de medicamentos.

\section{Vigilancia y control de la utilización de antibacterianos}

A pesar de que algunos países lograron controlar la venta de antibacterianos sin receta, el problema sigue sin resolverse en muchos países de nuestro continente.

- Hacer énfasis sobre la regulación sanitaria de los países, promover la legislación sobre la prescripción 
de antibacterianos y dispensación exclusivamente con receta y en farmacias, sancionando a los responsables de los canales de comercialización que no la cumplen.

- Estimular la vigilancia del consumo de antibacterianos a nivel nacional.

\section{Calidad}

Estimular el fortalecimiento de las entidades reguladoras nacionales para el control de la calidad de los antibacterianos, incluyendo en éstos la potencia y bioequivalencia de las formulaciones originales, copias y genéricos, en los casos que corresponda.

\section{Vacunación}

Debe promoverse la vacunación contra S. pneumoniae, Haemophilus influenzae tipo b y Neisseria meningitidis para disminuir su incidencia, y así disminuir la emergencia de resistencia en los mismos.

\section{Información}

- Hacer cumplir estándares éticos coherentes en toda la región para la relación entre la industria farmacéutica y el personal de salud, con el fin de promover el uso prudente de los antibacterianos.

- Aumentar la calidad y nivel de la información dirigida al público sobre el problema de la resistencia a los antibacterianos, y la necesidad de consumirlos sólo con prescripción médica y cumplir el tratamiento indicado. Para ello es necesario involucrar activamente al sector médico y farmacéutico, los Ministerios de Salud y principalmente a los medios de comunicación.

Este año, el Día Mundial de la Salud fue dedicado al problema de la resistencia a antibacterianos, lo cual puede representar una buena oportunidad para dar ímpetu a las acciones necesarias para contener este grave problema en América Latina.
T he bacterial resistance has worsened in this decade (2001-2011) hindering the election of antimicrobials (commonly called antibiotics), both for the treatment of acquired infections in the community, and for those originated in the hospital area.

In recent years the infections by multi-resistant bacteria have increased, also known by the press as "super-bugs", causes of high mortality and excessive costs.

The bacterial resistance already represents a threat to public health of Latin America. For this reason, experts in infectious diseases of the region call upon that governments, industry, health professionals and civil society to carry out comprehensive actions in order to contain the resistance to the bacterial control and safeguard these important drugs for the future generations.

\section{Background}

\section{Hospital infections}

In this area, the risk of acquiring infections produced by multi-resistant or extremely resistant strains increases in relation to:

- The unquestionable technology engineering and scientific development that has taken to improvements in the possibilities of life, especially in premature, elderly and in patients with different commitments, determining a hospital population with greater risk of morbidity and mortality.

- The lenght of hospitalization of the patients.

- The increase in invasive maneuvers (E.g.: mechanical ventilation or placement of urinary, intravenous or intra-arterial catheters) especially in the intensive care units.
- The increase in the placement of 'prosthetic` elements (bone replacements, pacemaker, "stents” coronary, etc.).

- Increase in hospital environments of gram-negative bacilli with multiple mechanisms of resistance (betalactamases of extended spectrum, hyperproducers of chromosomal betalactamases and especially new and multiple beta-lactamases carbapenemases that affect one of the last resources in available antibiotics: the carbapenems (e.g. `imipenem`, ‘meropenem `...).

- The troubling increase in the resistance to fluoroquinolones (Ie. ciprofloxacin, etc.) in Acinetobacter baumannii-calcoaceticus, Pseudomonas aeruginosa and recently in Klebsiella pneumoniae.

- Among the gram-positive, the increase in resistance to vancomycin and new antibiotics as linezolid or daptomycin, in Staphylococcus and 'Enterococci', principal causes of serious infections of high morbidity and mortality in the hospital environment.

\section{Infections in the community}

In recent years, infections have been increased by these multi-resistant bacteria in the community in patients unrelated to the hospital environment. The most noticeable example is the strains of community-acquired Staphylococcus aureus that are genetically different from the classical producers of hospital infections and they can cause from skin infections up to serious pulmonary injuries or in other vital organs.

There exist other examples of community microorganisms resistant to the antibacterials used for the treatment of the most frequent infections: 
- The increase in the frequency of isolation of gramnegative bacilli resistant in community patients.

- Loss of activity of the fluoroquinolones for urinary and respiratory infections.

- The appearance of infections is also troubling by Clostridium difficile, principal producer of diarrheal diseases by use and/or abuse of antibiotics.

- The notable increase in the resistance to macrolides and azalidos in Streptococccus pneumoniae (one of the most frequent causes of respiratory infections) and others gram-positive.

\section{Necessary actions toward a change}

Although the resistance to antibiotics is a global concern, in the context of Latin America, several problems that accentuate their severity are added:

- The permanent lack in many countries of resources from the national health budgets, which it is reflected by the deficiency in number and quality of structural resources, human (physicians, ‘microbiologists`, nurses, pharmacists, etc.) and of policy management.

- Poverty continues to be dramatic and with it, there a serious problem for the transmission of infections due mainly to overcrowding, that not only occurs in the household area, but often in the hospital itself. Furthermore, the lack of resources to acquire antibiotics is one of the factors that it joins together with the early interruption of the treatments and the suboptimal dosage, both associated with the increase in the bacterial resistance.

- Deficit in the information and advanced training in infectious diseases, microbiology, and epidemiology. There is a need for facilitating academic training courses of good clinical practice for physicians, laboratory, of nursing and administrators.

- Few hospitals have a service of hospital epidemiology and personnel with the adequate training.

- The absence in most of our hospitals of Infection Control Committees and/or those of Rational Use of Antibiotics, that they are indispensable for the correct and rational use of antibiotics in a hospital. They are also indispensable that they function in coordination within a formal and productive framework, as well as duly recognized and backed by the local Health Authority.

\section{Relation to livestock and veterinary}

- In the countries of Latin America with high level of livestock production and farming there is not sufficient surveillance on the abuse of large-scale antibiotics used for non-therapeutic purposes.
- The recent surveys in Latin America show an increase in consumption of antibiotics directed to pets prescribed by veterinarians. The excessive use of some antibiotics as rufloxacin and enrofloxacin gave rise to Escherichia coli resistant to all the fluoroquinolones. The joint activities should increase between the livestock sector, veterinarians and the devoted to human medicine.

- It is important to establish criteria on the time of the treatment and the classes for antibiotics permitted for use in animals, so that the resistance to antibiotics of critical importance is reduced for human medicine.

\section{The problem of the migrations and trips}

The `migratory` flow from rural centers of a single country or the neighboring countries toward large urban centers produce:

- The regional transfer of bacteria and other microorganisms of frequency and with resistance to these centers.

- The exposure of the migrants to the acquisition of coded genes of resistance that they abound in the large cities by the excessive use of bacterial control.

The procurement and transport of travelers from the different countries of the same or other continents of bacteria with genes of resistance that did not exist in the country where the traveler resides, it is another one of the causes that it increases the resistance to antibiotics.

\section{Quality of the microbiology laboratories}

Without detriment to the comprehensive evaluations of resistance made by some international resistance control programs, these do not cover most of laboratories of a country and its results may not to reflect the local reality.

It is necessary to promote that local Societies of Infectious Diseases and Microbiology conduct surveys and external quality control for the purpose of guaranteeing the quality of the tests of sensitivity to the antibacterials and it would be advisable that the Ministries of Health support these measures creating efficient mechanisms to disseminate the information obtained on the resistance, for the purpose of improving the medical prescription and the management in services of health, including medical education, treatment guidelines, hospital formularies and essential drug lists.

\section{Monitoring and control of the utilization of antibacterial agents}

Even though the some countries have managed to control the sale of antibacterials without a prescription, the problem still it is not resolved in many other countries of our continent. 
- Emphasize on the sanitary regulation of the countries, to promote legislation on the prescription of antibiotics and dispensing exclusively with prescription and in pharmacies, sanctioning to those responsible for the channels of marketing who do not fulfill it.

- Promote monitoring of consumption of antibiotics at the national level.

\section{Quality}

Promote the strengthening of the national regulatory entities for quality control of antibiotics, including the potency and bioequivalence of the original formulations, copies, and generics, in the cases that corresponds.

\section{Vaccination}

Should be promoted the vaccination against $S$. pneumoniae, Haemophilus influenzae type b, and Neisseria meningitidis in order to diminish its incidence, and thus diminish the resistance emergency in the same.

\section{Information}

- Enforce throughout the Region coherent ethical standards for the relationship between the pharmaceutical industry and the health workers, for the purpose of promoting the prudent use of antibiotics.

- Improve the quality and level of the information directed to the public on the problem of the resistance to antibiotics, and the need for consuming them only with medical prescription and fulfilling the indicated treatment. To this end it is necessary to involve actively the medical sector and pharmacist, the Ministries of Health and mainly to the communications media.

This year, World Health Day was devoted to the problem of the resistance to bacterial control, which it can provide a good opportunity to give impetus to the actions necessary for containing this serious problem in Latin America. 